\title{
電子機器試験のベテラン 遠矢秀機さん
}

電車の保安装置の保守で飯田記念 賞を受けた遠矢秀機さんを JR 東日 本の大井工場に訪ねた。

一一電子機器の試験がご専門なの ですね。

電車の保安装置であるATS（自 動列車停止装置) や ATC (自動列 車制御装置) の試験を主な仕事にし ています。この工場に入ってきた装 置がきちんと初期性能を示すか，も し示さないときは何が原因かを見極 めるわけです。電子回路として見れ ばかなり大規模な回路ですから, ど ういう手順で不調の原因に迫ってい くかがポイントで, 長年の経験と勘 が物を言うのです。最終的には，素 子レベルで診断します。

一一最近では山形新幹線の仕事を 手がけられたそうですね。

山形新幹線のモニタシステムは, 列車のスピードはもちろん, 架線電 圧やモー夕状態, ブレーキシリンダ の気圧から客室の室温や湿度にいた るまで，さまざまな情報を監視でき ますが，その総合試験を行いまし た。とくに山形新幹線の場合は東北 新幹線との連結・切り放しという特 殊事情がありますので, システムの 切り替えも重要な問題になってきま す。

—ソフト，ハードの両面にわた る試験ですから，大変でしょう。

ええ。考えられるすべての事象に

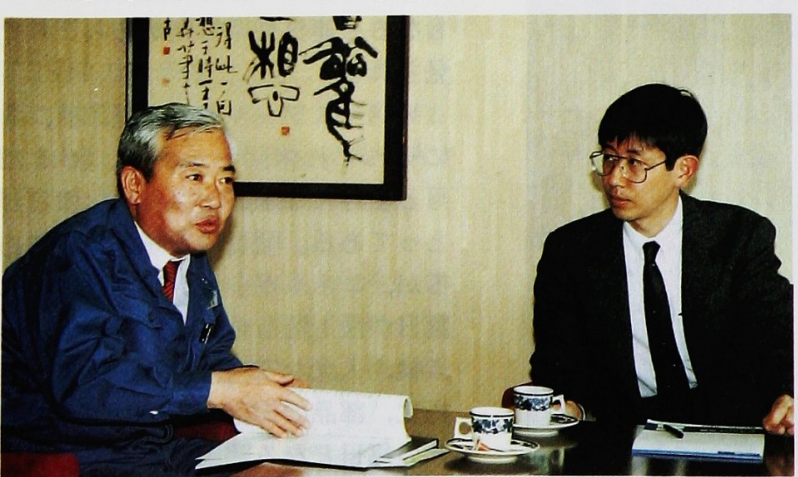

遠矢秀機氏 (左)

とインタビュア の吉江 修氏
とおや・ひでき 1942 年 8 月鹿児島市 に生まれる。現在, 東日本旅客鉄道 (株) 大井工場品質管理課で保全指導を 担当。 1990 年 5 月, 「電子機器の検査 方法の考察」で第 37 回飯田記念賞 （鉄道電化協会）受賞。

(II)」なんていうのは, 良い教科書 でしたね。今の仕事を始めたころ， 車両に積んでいるものといえば，真 空管を使った放送装置と車内警報装 置ぐらいのものでした。新しい装置 を作ろうと思ったら，すべて手作り です。社内教育がどうこうなんてい う時代ではなく，まさに試行錯誤の 連続でした。そんな中で昭和 43 年 ごろ，ATC III型の試験器を作り上 げたのです。

一現在は指導者として, 技術の 伝承ということも考えなければなら ない立場にあるわけですね。

基礎教育については社内で勉強会 を開いています。しかし本当に大切 なノウハウを身につけるには, 実地 訓練しかありません。故障の実例を 見せて，適切なアドバイスをするの です。そして，そのときの現象をと らえておくことが肝心です。測定で 得られた波形やそのときの条件を, 再現性のあるように記録しておく。 こうした地道な努力の積み重ねが大 切な財産になるんです。

理論と実践は，車の両輪の如し。 現場でたたき上げた感覚と, それを 裏付ける理論の, どちらが欠けても 難しいのだ。何はともあれ, その道 が好きであることが大切。設備の寿 命予測についてもお話を聞くことが でき，大変興味深かった。「ユーザ からのノウハウがメーカに正しくフ イードバックされねばならない」と いう言葉が，とても印象に残った。

聞き手・吉江 修 (東京理科大学) 